\title{
Hubungan Orang Tua Perokok dengan Status Refraksi pada Anak
}

\section{The Association of Parental Smoking and Refractive State on Children}

\author{
Nur Khoma F ${ }^{1}$, Nanda Wahyu $A^{2}$ \\ ${ }^{1}$ Fakultas Kedokteran Universitas Mulawarman Samarinda \\ ${ }^{2}$ Laboratorium IImu Kesehatan Mata Rumah Sakit Umum Dr. Saiful Anwar Malang
}

\begin{abstract}
ABSTRAK
Hubungan antara orang tua perokok dengan status refraksi sampai saat ini belum begitu jelas. Hasil penelitian secara eksperimental pada hewan coba dan secara observasional pada manusia mempunyai hasil yang berbeda. Penelitian ini bertujuan untuk mengetahui hubungan antara orang tua yang merokok dengan status refraksi dan parameter biometri okular pada anak. Penelitian ini merupakan suatu penelitian analitik observasional pada pasien yang berkunjung ke poli mata sub divisi refraksi periode 1 September 2011 sampai 30 April 2012 dan didiagnosa dengan miopia, emetropia atau hipermetropia. Parameter biometri okular diukur menggunakan biometri. Rerata ketebalan kornea sentral 536,89 $\pm 10,38$ $\mu \mathrm{m}$, panjang bola mata $24,11 \pm 1,29 \mathrm{~mm}$, kedalaman bilik mata depan 3,62 $\pm 0,29 \mathrm{~mm}$ dan ketebalan lensa 3,45 $\pm 0,15 \mathrm{~mm}$. Panjang bola mata dan kedalaman bilik mata depan didapatkan perbedaan yang bermakna antara kelompok dengan orang tua perokok dan yang tidak merokok. Orang tua perokok mempunyai hubungan yang signifikan dengan status refraksi, panjang bola mata dan kedalaman bilik mata depan, tetapi tidak berhubungan dengan ketebalan lensa.
\end{abstract}

Kata Kunci: Anak, orang tua, parameter biometri okular, rokok, status refraksi

\begin{abstract}
The relationship of parental smoking and refractive state on children was not clear. Experimental study and observational study had different result. The objective of this research was to understand the association between parental smoking and refractive state and biometric ocular parameters on children. It was an observasional analytic research on patients who visit eye polyclinic Saiful Anwar Hospital from September 2011 until April 2012. The diagnosis include myopia, emetropia and hypermetropia. Ocular biometric parameters were measured by using biometry. Mean axial length was 24,11 $\pm 1,29$

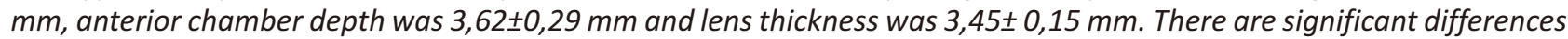
axial length and anterior chamber depth between parental smoking and non parental smoking group. P-value of Spearman correlation test of parental smoking and refractive state, axial length and anterior chamber depth was $<0,05$ of each. P-value of Spearman correlation test of parental smoking and lens thickness was 0,339. Parental smoking was significantly related to refractive state, axial length and anterior chamber depth but not related to lens thickness
\end{abstract}

Keywords: Children, ocular biometrics, parent, refractive state, smoking

Jurnal Kedokteran Brawijaya, Vol. 27, No. 4, Agustus 2013; Korespondensi: Nur Khoma F. Fakultas Kedokteran Universitas Mulawarman Samarinda, Jl. Kerayan Kampus Gunung Kelua Samarinda 751119 Tel. (0541) 7488581 Email: gusma_riqo@yahoo.com 


\section{PENDAHULUAN}

Penurunan tajam penglihatan pada anak akibat kelainan refraksi masih tinggi dan masih menjadi masalah kesehatan terutama di negara berkembang. Data WHO pada tahun 2004 menunjukkan 0,97\% anak usia 5 tahun sampai 15 tahun di seluruh dunia mengalami penurunan tajam penglihatan akibat kelainan refraksi yang tidak dikoreks (1). Di Indonesia, survei kesehatan rumah tangga pada tahun 2004 mendapatkan data gangguan kegiatan sehari-hari yang diakibatkan oleh gangguan penglihatan adalah sebesar $71 \%$, dengan $22,1 \%$ diakibatkan oleh kelainan refraksi serta $15 \%$ terjadi pada anak usia 5-15 tahun, sedangkan angka pemakaian kaca mata masih $12,5 \%$ dari kebutuhan (2).

Sampai saat ini penyebab pasti terjadinya kelainan refraksi pada anak masih banyak diteliti. Faktor yang diduga mempunyai pengaruh terjadinya kelainan refraksi antara lain pemanjangan bola mata, kekuatan refraksi kornea, kekuatan refraksi lensa, riwayat keluarga dengan kelainan refraksi. Teori yang berkembang pada saat ini dikatakan bahwa nikotin juga mempunyai peran mempengaruhi pertumbuhan bola mata, yang pada akhirnya mempengaruhi status refraksi (3-6). Nikotin mempengaruhi pertumbuhan bola mata melalui reseptor muskarinik. Eksperimen pada ayam menunjukkan bahwa pemberian antagonis nikotin menghambat perluasan kavitas vitreus dan perpanjangan bola mata (6). Paparan nikotin pada asap rokok diduga dapat mengaktifkan reseptor muskarinik.

Hasil penelitian yang dilakukan oleh Su et al pada anak usia 6-72 bulan didapatkan bahwa adanya ayah yang perokok akan menurunkan kemungkinan terjadinya miopia sebesar $0,7 \%$, sedangkan ibu yang perokok akan menurunkan kemungkinan terjadinya miopia sebesar $0,3 \%$. Hasil temuan ini bertolak belakang dengan hasil penelitian yang dilakukan oleh Stone et al secara eksperimental pada hewan coba. Penelitian Stone membuktikan bahwa pemberian antagonis nikotin akan menghambat pertumbuhan bola mata sehingga progresifitas miopia dapat dihambat (6-7). Penelitian ini bertujuan untuk mengetahui apakah ada hubungan antara orang tua perokok dengan status refraksi dan parameter biometri okular pada anak. Di duga kedua variabel tersebut mempunyai hubungan yang erat.

\section{METODE}

Penelitian ini menggunakan desain cross sectional pada semua pasien anak yang datang di poli mata subdivisi refraksi antra 1 September 2011 sampai 30 April 2012 baik pasien baru atau pasien lama dan didiagnosa dengan miopia, hipermetropia atau emetropia dan memenuhi kriteria inklusi. Kriteria inklusi pada penelitian ini antara lain usia antara 5 tahun sampai 14 tahun, pasien tidak mengalami mata merah, pseudofakia, afakia dan orang tua bersedia untuk dilakukan pemeriksaan pada anaknya dan mengisi kuesioner serta menandatangani surat persetujuan untuk menjadi subjek penelitian. Subjek dieksklusi apabila selama pemeriksaan pasien tidak kooperatif sehingga tidak dapat dilakukan pemeriksaan.

Pemeriksaan yang dilakukan adalah pemeriksaan tajam penglihatan dan koreksi tajam penglihatan yang terbaik menggunakan alat trial-lens, dan kemudian dikategorikan dalam miopia, emetropia dan hipermetropia berdasarkan koreksi yang terbaik. Parameter biometri okular yang diukur adalah panjang bola mata, kedalaman bilik mata depan dan ketebalan lensa menggunakan Biometri (Tomey UD-6000) dan dinyatakan dengan millimeter ( $\mathrm{mm}$ ). Berdasarkan data yang diisi, pasien dikelompokkan menjadi dua kelompok yaitu kelompok dengan orang tua perokok yaitu apabila salah satu dari kedua orang tua atau keduanya mempunyai kebiasaan merokok sehingga menyebabkan anak terpapar asap rokok sejak lahir sampai saat ini.

Untuk mengetahui perbedaan parameter biometri okular antara kelompok dengan orang tua perokok dan yang tidak merokok dilakukan uji t-test independent. Untuk mengetahui hubungan antara orang tua perokok dengan status refraksi serta parameter biometri okular dilakukan uji Spearman.

\section{HASIL}

Pada penelitian ini didapatkan 114 anak (228 mata), terdiri dari 55 laki-laki dan 59 perempuan. Hasil pemeriksaan menunjukkan 121 mata tergolong dalam kategori miopia, 93 mata tergolong emetropia dan 14 mata tergolong hipermetropia, dan semua berasal dari suku Jawa.

Karakteristik usia pasien rata-rata 10,37 $\pm 1,96$ tahun. Antara kelompok sampel dengan orang tua perokok dan yang bukan perokok mempunyai karakteristik usia yang tidak berbeda bermakna. Pada kelompok dengan orang tua perokok mempunyai usia 10,35 tahun sedang pada yang bukan perokok 10,40 tahun. Rerata panjang bola mata pada semua sampel adalah $24,11 \pm 1,29 \mathrm{~mm}$, kedalaman bilik mata depan 3,62 $\pm 0,29 \mathrm{~mm}$ dan ketebalan lensa 3,45 $\pm 0,15 \mathrm{~mm}$.

Sebaran jenis kelamin antara kelompok dengan orang tua perokok dan yang bukan perokok hampir sama. Pada kelompok dengan orang tua perokok jenis kelamin laki-laki sebanyak 26 anak, perempuan 29 anak, sedangkan pada kelompok dengan orang tua bukan perokok didapatkan jenis kelamin laki-laki sebanyak 29 anak dan perempuan 30 anak. Berdasarkan status refraksi, pada kelompok miopia didapatkan jenis kelamin laki-laki sebanyak 24 anak dan perempuan sebanyak 37 anak. Pada kelompok hipermetropia didapatkan jenis kelamin laki-laki sebanyak 27 anak dan perempuan 20 anak. Untuk kelompok emetropia didapatkan jenis kelamin laki-laki sebanyak 4 anak dan perempuan 3 anak.

Riwayat paparan dengan asap rokok sejak dalam kandungan didapatkan lebih besar pada pasien dengan kelainan refraksi. Sebanyak 77,7\% pasien miopia terpapar dengan asap rokok. Pada pasien hipermetropia sebanyak $85,7 \%$ pasien terpapar asap rokok. Pasien dengan emetropia yang terpapar dengan asap rokok sejak kehamilan jauh lebih sedikit yaitu $23,7 \%$.

Tabel 1. Tabulasi silang karakteristik pasien dan status refraksi

\begin{tabular}{llcc}
\hline \multirow{2}{*}{ Karakteristik } & \multicolumn{3}{c}{ Status Refraksi } \\
\cline { 2 - 4 } & Miopia & Emmetropia & Hipermetropia \\
\hline Jenis Kelamin & 24 & 4 & 27 \\
$\square$ Lelaki & 37 & 3 & 20 \\
$\square$ Perempuan & & & \\
Status Merokok Orang tua & & 23,7 & 85,7 \\
$\square$ Perokok & $77,7 \%$ & 76,3 & 14,3 \\
$\square$ Bukan & $22,3 \%$ & & \\
\hline
\end{tabular}


Rerata panjang bola mata antara kelompok dengan orang tua perokok dan bukan perokok mempunyai perbedaan yang signifikan. Panjang bola mata kelompok dengan orang tua perokok adalah $24,37 \mathrm{~mm}$ dan kelompok dengan orang tua bukan perokok mempunyai panjang bola mata $23,77 \mathrm{~mm}$. Rerata kedalaman bilik mata depan mata antara kelompok dengan orang tua perokok dan bukan perokok mempunyai perbedaan yang signifikan. Kedalaman bilik mata depan kelompok dengan orang tua perokok adalah 3,67 mm dan kelompok dengan orang tua bukan perokok mempunyai kedalaman bilik mata depan 3,54 $\mathrm{mm}$. Uji korelasi Spearman test antara orang tua perokok dengan kedalaman bilik mata depan menunjukkan hubungan yang signifikan. Rerata ketebalan lensa antara kelompok dengan orang tua perokok dan bukan perokok tidak berbeda bermakna $(p=0,339)$. Ketebalan lensa kelompok orang tua perokok adalah 3,45 dan kelompok dengan orang tua bukan perokok mempunyai ketebalan lensa 3,44 $\mathrm{mm}$. Dari hasil penelitian ini kita dapat mengetahui bahwa ketebalan lensa tidak berhubungan dengan paparan asap rokok, berbeda dengan panjang bola mata dan kedalaman bilik mata depan yang lebih berhubungan dengan paparan asap rokok.

Tabel 2. Perbedaan nilai parameter biometri okular berdasarkan status merokok orang tua

\begin{tabular}{llcl}
\hline Parameter & Merokok & Tidak merokok & $\mathbf{p}$ \\
\hline Panjang bola mata & 24,37 & 23,77 & 0,03 \\
Kedalaman bilik mata & $3,67 \mathrm{~mm}$ & 3,54 & 0,04 \\
Ketebalan lensa & 3,45 & 3,44 & 0,339 \\
\hline
\end{tabular}

\section{DISKUSI}

Hasil penelitian ini menunjukkan riwayat orang tua merokok banyak didapatkan pada anak dengan kelainan refraksi yaitu pada miopia dan hipermetropia, sedangkan pada keadaan emetropia lebih banyak didapatkan orang tua yang bukan perokok. Hasil uji Spearman menunjukkan bahwa orang tua perokok mempunyai hubungan yang signifikan dengan kelainan refraksi. Pada penelitian ini tidak dibedakan apakah paparan asap rokok berasal dari salah satu orang tua atau kedua orang tua.

\section{DAFTAR PUSTAKA}

1. Resnikoff S, Pascolini D, Mariotti SP, and Pokharel GP. Global Magnitude of Visual Impairment Caused by Uncorrected Refractive Errors in 2004. Bulletin of The World Health Organization. 2008; 86(1): 63-70.

2. Departemen Kesehatan RI. Survey Kesehatan Rumah Tangga. Jakarta: Departemen Kesehatan RI; 2002.

3. Ip JM, Huynh SC, Kifley A, et al. Variation of the Contribution from Axial Length and Other Oculometric Parameters to Refraction by Age and Ethnicity. Investigative Ophthalmology and Visual Science. 2007; 48(10): 4846-4853.

4. Lam DSC, Fan DSP, Lam RF, et al. The Effect of Parental History of Myopia on Children's Eye Size and Growth: Results of a Longitudinal Study. Investigative
Demikian pula pada penelitian ini tidak digali lebih jauh berapa dosis atau jumlah rokok yang dikonsumsi setiap harinya.

Hasil penelitian ini berbeda dengan hasil penelitian yang dilakukan oleh Stone yang menyimpulkan bahwa orang tua yang merokok sedikit berhubungan dengan terjadinya miopia dan lebih menunjukkan adanya hubungan dengan keadaan hipermetropia. Pada penelitian tersebut juga dibedakan antara pengaruh paparan asap rokok pasif dari salah satu orang tua atau dari kedua orang tua. Paparan asap rokok secara pasif dari salah satu orang tua mempunyai hubungan yang sangat lemah dengan status refraksi apabila dibandingkan dengan paparan asap rokok pasif dari kedua orang tua $(5,8,9)$.

Hasil penelitian ini menunjukkan bahwa pada kelompok dengan orang tua perokok mempunyai bola mata dan kedalaman bilik mata depan yang lebih panjang dibandingkan dengan orang tua bukan perokok. Hal yang menarik adalah ketebalan lensa tidak berbeda antara kedua kelompok. Hasil studi secara eksperimental pada hewan coba menunjukkan bahwa nikotin berpengaruh pada pertumbuhan bola mata, dan yang paling dipengaruhi adalah panjang bola mata dan kavitas vitreus (6).

Nikotin bekerja pada reseptor asetilkolin dan diduga mempengaruhi perkembangan refraksi. Sebagian besar penelitian menunjukkan bahwa reseptor muskarinik yang merupakan reseptor metabotrofik yang bekerja melalui protein G, mempengaruhi terjadinya miopia. Dua obat antagonis non selektif nikotin yaitu chlorisondamine dan mecamylamine mempunyai efek menghambat myopia. Pada dosis yang tinggi, chlorisondamine menghambat terjadinya miopia dengan menurunkan kavitas vitreus dan perpanjangan bola mata. Mecamylamine pada dosis 50 mg juga menghambat terjadinya perpanjangan bola mata yang berlebihan. Penghambatan perluasan kavitas vitreus oleh antagonis nikotin mungkin akibat kerja obat ini pada tingkat regulasi neural dari pertumbuhan bola mata yang berbeda dengan bahan lain yang bekerja pada dimensi aksial (6,10-11). Hasil yang didapat dari penelitian ini menunjukkan bahwa orang tua perokok berhubungan dengan status refraksi pada anak dan cenderung ke arah miopia. Parameter yang lebih dipengaruhi adalah panjang bola mata dan kedalaman bilik mata depan.

Ophthalmology and Visual Science. 2008; 49(3): 873876.

5. Stone RA, Wilson LB, Ying G-s, et al. Associations between Childhood Refraction and Parental Smoking. Investigative Ophthalmology and Visual Science. 2006; 47(10): 4277-4287.

6. Su DH, Wong TY, Foster PJ, Tay WT, Saw SM, and Aung T. Central Corneal Thickness and its Associations with Ocular and Systemic Factors: The Singapore Malay Eye Study. American Journal of Ophthalmology. 2009; 147(4): 709-716.

7. Stone RA, Sugimoto R, Gill AS, Liu J, Capehart C, and Lindstrom JM. Effects of Nicotinic Antagonists on Ocular Growth and Experimental Myopia. Investigative Ophthalmology and Visual Science. 
2001; 42(3): 557-565.

8. Bhat S, Elias A, G Mahesh, Kumar R, and Giridhar A. The Relationship of Central Corneal Thickness and Related Factors in Myopes and Emmetropes. AIOC 2010 Proceedings. India, 2010.

9. Saw SM, Shankar A, Tan SB, et al. A Cohort Study of Incident Myopia in Singaporean Children. Investigative Ophthalmology and Visual Science. 2006; 47(5): 1839-1844.
10. Gwiazda J, Marsh-Tootle WL, Hyman L, Hussein M, Norton TT, and Group CS. Baseline Refractive and Ocular Component Measures of Children Enrolled in the Correction of Myopia Evaluation Trial (COMET). Investigative Ophthalmology and Visual Science. 2002; 43(2): 314-321.

11. Saw SM, Carkeet A, Chia KS, Stone RA, and Tan DTH. Component Dependent Risk Factors for Ocular Parameters in Singapore Chinese Children. Ophthalmology. 2002; 109(11): 2065-2071. 